\title{
Banana Bunchy Top Viral Coat Protein (CP) Gene Expression Studies at Molecular Level in Hill Banana cv. Sirumalai (AAB)
}

\author{
Chandrasekar Arumugam*, Kalaiponmani Kalaimughilan and Angappan Kathithachalam \\ Department of Plant Biotechnology, Centre for Plant Molecular Biology and Biotechnology, \\ Tamilnadu Agricultural University, Coimbatore -641003, India \\ *Corresponding author
}

\section{A B S T R A C T}

\begin{tabular}{|c|}
\hline Keywords \\
\hline $\begin{array}{l}\text { Banana, BBTV, } \\
\text { CP, PCR, } \\
\text { Cloning, } \\
\text { Southern blot, } \\
\text { Expression vector. }\end{array}$ \\
\hline Article Info \\
\hline $\begin{array}{l}\text { Accepted: } \\
\text { 04 May } 2017 \\
\text { Available Online: } \\
10 \text { June } 2017\end{array}$ \\
\hline
\end{tabular}

Bunchy top disease caused by the banana bunchy top virus (BBTV) is a serious disease in hill banana. Detection of the BBTV infection in the planting material could help in the effective management of the disease. Primers were designed for the PCR amplification of BBTV coat protein (CP). In the present study, to confirm the virus infection and to quantify the viral load in the plants, samples from infected and healthy banana were subjected to PCR and southern blot hybridization. There was no distinguishable difference in viral load with respect to age of the plants was observed. The BBTV capsid protein (CP) gene located on component 3 was cloned in an expression vector pET28a (+). Expression of the CP in E. coli BL21 cells was induced by adding isopropyl-3-D-1-thiogalactoside (IPTG) to a final concentration of $1 \mathrm{~mm}$. The expressed CP which migrated as a protein of approximately $19.5 \mathrm{kDa}$ in Sodium Dodecyl Sulphate (SDS)-polyacrylamide gel electrophoresis (PAGE) was identified by its molecular weight. Hence it is concluded that the CP gene of BBTV was cloned and expressed in E. coli can be used for antibody rising or adding an affinity purification tag will enable us to produce pure monoclonal antibody in future.

\section{Introduction}

Banana (Musa spp.) is one of the most important fruit crop in the world (Dale et al., 1987). It is the major staple food crop for approximately 400 million people. In India, banana is cultivated in Karnataka, Tamil Nadu, Gujarat, Maharastra, Andhra Pradesh, Assam and Kerala. The main varieties of banana are Dwarf Cavendish, Bhusaval Keli, Basrai, Poovan, Harichhal, Nendran, Safed velchi, Robusta and Grand naine. Among the states Gujarat has the highest productivity of 177.5 metric tonnes against India's average of 35.50 metric tonnes. Banana is affected by various yield limiting factors such as pests, and diseases. Diseases like black sigatoka (Mycosphaerella fijiensis), wilt (Fusarium oxysporum), viruses like banana bunchy top virus (BBTV), banana streak virus (BSV), banana bract mosaic virus (BBMV) and nematodes cause significant yield losses (Tripathi et al., 2004). Long generation time, various levels of ploidy, lack of genetic variability and sterility of most edible cultivars have hampered the development of disease-resistant Musa by conventional breeding. 
Several approaches have been attempted to manage bunchy top disease in banana and none of the strategies was able to give $100 \%$ protection. The strategies include planting of disease free plantlets from disease free stock clumps, regular inspection for bunchy top disease, removal and destruction of diseased plants. Research progress in understanding the mechanism of resistance to this disease has been very slow in comparison with many other serious viral diseases because of the problems in purifying the virus.

Banana bunchy top disease, caused by BBTV is the devastating viral disease of banana. BBTV was first recorded during 1889 in Fiji. BBTV is transmitted in persistent, circulative manner by the black banana aphid (Pentalonia nigronervosa) (Singh et al., 1996; Valerie et al., 2001). The infected plants with advanced symptoms have a rosette appearance with narrow, upright and progressively shorter leaves, giving rise to the common name "bunchy top ". The leaf edges often roll upwards and show a marginal yellowing. Dark green streaks are often found on midrib and petiole, extending down into the pseudostem. The most effective diagnostic symptom is short dark green dots and dashes (Fig. 1) along the minor leaf veins. In Tamil $\mathrm{Nadu}$, it is a very serious disease in lower Pulney hills where the ecotypes of hill banana, Virupakshi and Sirumalai (AAB) are cultivated (Fig. 2).

Molecular investigations on BBTV genome revealed that BBTV has isometric virions (Harding et al., 1991; Katul et al., 1997; Su et al., 2000), 18-20 $\mathrm{nm}$ in diameter, and a multicomponent genome consists of at least six circular single stranded DNA (ssDNA) component (BBTV DNA-1 to 6) ranging in size from 1108 bp to 1111 bp (Burns et al., 1994 and 1995; Karan et al., 1997; Wanitchakorn et al., 1997; Beetham et al., 1999). BBTV virions have a single coat protein of approximately $20 \mathrm{kDa}$ (Thomas and Dietzen, 1991). Several approaches have been attempted to manage bunchy top disease in banana and none of the strategies was able to give $100 \%$ protection (Karan et al., 1994; Horser et al., 2001). The strategies include planting of disease free plantlets from disease free stock clumps, regular inspection for bunchy top disease, removal and destruction of diseased plants (Amain et al., 2008). Research progress in understanding the mechanism of resistance to this disease has been very slow in comparison with many other serious viral diseases because of the problems in purifying the virus $(\mathrm{Wu}$ and $\mathrm{Su}$, 1990). This is because of the presence of large amounts of latex and phenolic compounds in banana tissue which interfere with virus extraction and purification (Dale et al., 1986).

Successful control of bunchy top disease depends on the availability of reliable BBTV detection methods which will help us to select disease free plantlets. Symptoms of bunchy top disease are not visible at the time of planting. Hence, development of a detection kit for quick detection of BBTV is essential for diagnosis of the disease at the time of planting. Enzyme Linked Immunosorbant Assay (ELISA) is convenient and easy method but it has a limitation of being less sensitive when the viral load is low (Landgraf et al., 1991). In this context, Nucleic acid based polymerase chain reaction (PCR) (Edwards and Gibbs, 1994; Grieco and Gallitelli, 1999; Tettelin et al., 1999; Olmos et al., 2002; Stellrecht et al., 2004) and hybridization methods have the advantage of amplifying the target nucleic acid present even at very low level and it has become an attractive technique for the diagnosis of plant viral diseases (Mullis et al., 1986; Henson and French, 1993; Xie and $\mathrm{Hu}, 1994$; McManus and Jones, 1995; Hafner et al., 1997a and b; Elnifro et al., 2000; Nassuth et al., 2000). 


\section{Materials and Methods}

\section{Collection of plant sample}

Hill banana field trial was conducted at Horticulture Research Station (HRS), Tamil Nadu Agricultural University, Thadiyankudisai (Lower Pulney Hills). Thirty hill banana suckers infected with BBTV were collected from HRS and 30 tissue culture and certified hill banana suckers free from BBTV infection were collected from National Research Centre for Banana NRCB, Trichirapalli and used as planting material for field trial. The leaf samples were collected from the plants at two different stages viz., juvenile stage ( 3 months after planting) and vegetative stage (6 months after planting). Healthy tissue culture derived plants were grown negative control.

\section{Total genomic DNA extraction from banana leaves}

Fresh young emerging green leaves with midribs were collected from the field trial plants and DNA was isolated and stored at $20^{\circ} \mathrm{C}$ for further use. Genomic DNA was isolated using the modified CTAB (Cetyl Trimethyl Ammonium Bromide) protocol (Sambrook et al., 1989). Prior to extraction, 100 to $300 \mathrm{mg}$ of midrib of young hill banana leaves were cut into bits and transferred to a zip lock bag $(7 \times 9 \mathrm{~cm})$. Extraction CTAB buffer $1 \mathrm{ml}(0.2 \mathrm{M}$ EDTA, $1.4 \mathrm{M} \mathrm{NaCl}, 1 \mathrm{M}$, CTAB $2 \%$ ) was added immediately. The samples were kept at room temperature and squeezed by rolling a glass rod over the sample to extract the cell contents. About 500 $\mu l$ of the cell extract was transferred into an eppendorf tube, and then $33 \mu \mathrm{l}$ of $20 \%$ SDS was added into the tube and mixed well. The tube was kept at $65^{\circ} \mathrm{C}$ (heating blocks) for 10-12 min and then the tube was centrifuged for 10 minutes at $12,000 \mathrm{rpm}$ and $450 \mu \mathrm{l}$ of the supernatant was transferred immediately to a new eppendorf tube, and $450 \mu \mathrm{l}$ of ice cold IPA (Isopropyl alcohol) was added and after mixing, the tubes were kept in ice for 20 $\mathrm{min}$. The tubes were centrifuged for $15 \mathrm{~min}$ at $12,000 \mathrm{rpm}$ and supernatant was discarded without disturbing the pellet. The pellet was washed with $500 \mu \mathrm{l}$ of $70 \%$ ice cold ethanol and centrifuged for $10 \mathrm{~min}$ at $12,000 \mathrm{rpm}$. The supernatant was discarded and the pellet was air dried for 5 min and suspended in 40 $\mu \mathrm{l}$ of $0.1 \mathrm{X}$ TE buffer $(1 \mathrm{mM}$ Tris $\mathrm{HCl} \mathrm{pH} 8.0$ and $0.1 \mathrm{mM}$ EDTA pH 8.0) and kept at $65^{\circ} \mathrm{C}$ for $3 \mathrm{~min}$ (to suspend the pellet well) and stored at $-20^{\circ} \mathrm{C}$. The isolated DNA was checked for its purity by $0.8 \%$ agarose gel electrophoresis and quantified by UV Spectrophotometer.

\section{Multiple sequence alignment and primer designing}

ClustalW (Thompson et al., 1997) program was used for multiple sequence alignment of retrieved sequences of different BBTV isolates. Conserved blocks in the BBTV genome sequence were identified after sequence alignment. Primer 3 software was used for designing primers (Table 1). Primer quality parameters like GC percentage, melting temperature and product size were taken into consideration and worthiness of the designed primer was analyzed using Fast PCR software.

\section{PCR screening of BBTV infection in hill banana}

PCR amplification was performed to amplify the CP gene. DNA samples isolated from the hill banana leaf samples were used as template. PCR reaction were performed in a final volume of $20 \mu \mathrm{l}, 2 \mu \mathrm{l}$ diluted total genomic DNA, $2.0 \mu \mathrm{l}$ of 10X PCR buffer (10 $\mathrm{mM}$ Tris- $\mathrm{HCl}, \mathrm{pH} 9.0,50 \mathrm{mM} \mathrm{KCl}, 1.5 \mathrm{mM}$ $\left.\mathrm{MgCl}_{2}\right), 0.5 \mu \mathrm{l}$ of $200 \mathrm{mM}$ dNTPs, $1 \mu 1$ of 100 ng of respective forward and reverse primers, 
$0.5 \mu \mathrm{l}$ of $3 \mathrm{U}$ Taq DNA polymerase (Bangalore Genei Pvt. Ltd., Bangalore, India) and $14 \mu \mathrm{l}$ of sterilized double distilled water. Amplification was performed in a PTC100TM Programmable Thermal Cycler (MJ Research, Inc., Watertown, USA). The temperature profile is as follows: Initial denaturation at $94^{\circ} \mathrm{C}$ for $5 \mathrm{~min}, 35$ cycles of denaturation at $94^{\circ} \mathrm{C}$ for $1 \mathrm{~min}$ annealing at $57^{\circ} \mathrm{C}$ for $1 \mathrm{~min}$, extention at $72^{\circ} \mathrm{C}$ for $1 \mathrm{~min}$ and final extension for $10 \mathrm{~min}$ at $72^{\circ} \mathrm{C}$. After amplification, $8 \mu \mathrm{l}$ of the product was used for electrophoretic analysis on $0.8 \%$ agarose gels.

\section{Agarose gel electrophoresis}

The PCR products were resolved on $0.8 \%$ agarose gel was prepared and to this $2 \mu \mathrm{l}$ ethidium bromide was added from the stock $(10 \mathrm{mg} / \mathrm{ml})$. After cooling, the mixture was poured into a preset template using an appropriate comb. The comb was removed after solidification and gel with template was placed in a horizontal electrophoresis unit containing $1 \mathrm{X}$ TBE buffer.

The PCR product was mixed with $6 \mathrm{X}$ loading dye at 5:1 ratio and loaded. Electrophoresis was carried out at 60V (Sambrook et al., 1989). After the gel electrophoresis, the amplified DNA bands were visualized under UV transilluminator.

\section{PCR Amplification of coat protein (CP)}

PCR analysis was performed to amplify the $\mathrm{CP}$ gene in the DNA samples isolated from the hill banana leaf samples collected from the field trial (Fig. 2). The reactions were carried out in a reaction volume of $20 \mu \mathrm{l}$ and by following the temperature profiles as described above. After amplification, $10 \mu \mathrm{l}$ of the PCR product was electrophoresed in a $0.8 \%$ agarose gel and bands were visualized by ethidium bromide staining.

\section{Cloning and sequencing of $\mathrm{CP}$ gene}

\section{Cloning of CP gene}

PCR amplification of CP gene was done using the designed forward and reverse primer. PCR amplified product was resolved by agarose gel electrophoresis. DNA band of expected 513 bp size (Fig. 3) was excised from the gel and the DNA fragment was eluted using gel extraction kit by following manufacturer's instructions (Sigma, USA). The eluted DNA fragment was ligated into a $\mathrm{T}$-tailed vector pTZ57R/T by T/A cloning method (catalog \# K1214; MBI Fermentas).

Ligation reaction was set up by mixing $50 \mathrm{ng}$ of vector DNA, $150 \mathrm{ng}$ of amplified product, $1 \mathrm{U}$ of T4 DNA ligase and $1 \mu \mathrm{l}$ of $10 \mathrm{X}$ buffer in a $10 \mu \mathrm{l}$ reaction. The reaction mix was incubated at $16^{\circ} \mathrm{C}$ for $16 \mathrm{~h}$ and the ligated product transformed into competent $E$. coli (DH5 $\alpha)$ cells. The recombinant white colonies were selected and screened for the recombinant plasmid by colony PCR analysis.

\section{Colony PCR analysis}

Colony PCR analysis was done to identify the recombinant clones by using the $\mathrm{CP}$ gene specific primers. Reactions were performed in a final volume of $20 \mu \mathrm{l}(2 \mu \mathrm{l}$ of diluted total genomic DNA, $2.0 \mu 1$ of 10X PCR buffer (10 $\mathrm{mM}$ Tris- $\mathrm{HCl}, \mathrm{pH} 9.0,50 \mathrm{mM} \mathrm{KCl}, 1.5 \mathrm{mM}$ $\mathrm{MgCl} 2), 0.5 \mu \mathrm{l}$ of $200 \mathrm{mM}$ dNTPs, $1 \mu \mathrm{l}$ of $100 \mathrm{ng}$ of forward (ATGGCTAGGT ATCCGAAG) and reverse primer (TCAAA CATGATATGTAATTC), $0.5 \mu \mathrm{l}$ of 3U Taq DNA polymerase (Bangalore Genei Pvt. Ltd., Bangalore, India) and $14 \mu \mathrm{l}$ of sterilized double distilled water.

Amplification was performed in a PTC100TM Programmable Thermal Cycler (MJ Research, Inc., Watertown, USA). 
The temperature profile used in the amplification was as followes; Initial denaturation at $94^{\circ} \mathrm{C}$ for $5 \mathrm{~min}$ followed by 35 cycles of $94^{\circ} \mathrm{C}$ for $1 \mathrm{~min}, 57^{\circ} \mathrm{C}$ for $1 \mathrm{~min}$, $72^{\circ} \mathrm{C}$ for $1 \mathrm{~min}$ and final extension for $10 \mathrm{~min}$ at $72^{\circ} \mathrm{C}$. After amplification, $8 \mu \mathrm{l}$ of the product was used for electrophoretic analysis on $1 \%$ agarose gels.

\section{Sequencing of the coat protein}

The isolated recombinant plasmid was sequenced (NCBI accession number: FJ664271.1). The obtained nucleotide sequences were analyzed through NCBIBLAST search.

Multiple sequence alignment was performed using ClustalW program to analyze the similarity between the cloned insert and the gene sequence 513 base pair retrieved from the database.

\section{NCBI accession number: FJ664271.1}

ATGGCTAGGTATCCGAAGAAATCCATC AAGCAGAGGCGGGTTGGGCGCCGGAA GTATGGCAGCAAGGCGGTAACGAGCC ACGACTACTCGTCGTTAGGGTCAATAT TGGTTCCTGAAAACACCGTCAAGGTAT TTCGGATTGAGCCTACTGATAAAACAT TACCCAGATATTTTATCTGGAAAATGT TTATGCTTCTTGTGTGCAAGGTGAAGC CCGGAAGAATACTTCATTGGGCTATGA TCAAGAGTTCTTGGGAAATCAACCAGC CGACAACCTGTCTGGAAGCCCCAGGTT TATTTATTAAACCTGAACATAGCCATC TGGTTAAACTGGTATGTAGTGGGGAAC TTGAAGCAGGAGTCGCAACAGGGACA TCAGATGTTGAATGTCTTTTGAGGAAG ACAACCGTGTTGAGGAAGAATGTAAC AGAGGTGGATTATTTATATTTGGCATT CTATTGTAGTTCTGGAGTAAGTATAAA CTACCAGAACAGAATTACATATCATGT TTGA

\section{Southern blot analysis}

\section{Restriction digestion of genomic DNA}

Restriction digestion was done according to Sambrook et al., (1989). The banana genomic DNA was restricted with the restriction endonucleases, Hind III (2 units of enzyme per $\mu \mathrm{g}$ of DNA) in recommended buffer, at $37 \mathrm{oC}$, overnight.

Reaction was analyzed by $0.8 \%$ agarose gel electrophoresis along with undigested banana DNA as control.

\section{Southern blotting}

Equal amount of restricted genomic DNAs $(10 \mu \mathrm{g} /$ /ane $)$ were resolved on a $0.8 \%$ agarose gel. After electrophoresis, the gel was immersed in $0.25 \mathrm{~N}$ Hydrochloric acid for 15 minutes for partial depurination of DNA. After depurination, incubating the gel in 0.4 M sodium hydroxide for 20 minutes denatured DNA. After soaking the gel in 10X SSC for 30 minutes, the gel was placed carefully on transfer platform covered with a Whatman $3 \mathrm{~mm}$ filter paper wick with its margins hanging in 10X SSC poured in a glass tray, a piece of nylon filter, cut marginally smaller than the gel, was placed carefully on the gel.

Nylon filter was covered immediately with 5 sheets of whatman $3 \mathrm{~mm}$ filter papers and then with a stack of crude filter papers, cut exactly to the dimensions of the gel. The stack of filter papers was covered with a glass plate, over which a weight of $500 \mathrm{~g}$ was placed.

The level of 10X SSC should be below the surface of the platform. The upward diffusion of the buffer was allowed for 18 hours. After transfer, the nylon filter was carefully removed, cross linked against UV light for 50 seconds, rinsed with 2X SSC and dried. 


\section{Preparation of radiolabeled probes}

The DNA was amplified using CP gene PCR by, following standard procedure (Sambrook et al., 1989). About $25 \mathrm{ng}$ of DNA fragments was denatured with $0.5 \mu \mathrm{g}$ of random hexanucleotide primers in a boiling water bath for 5 minutes and chilled immediately on ice. To the mixture, other reaction compounds are added to set a $25 \mu 1$ reaction containing 25 $\mu \mathrm{M}$ each of $0.33 \mathrm{mM}$ dATP, $0.33 \mathrm{mM}$ dTTP, and $0.33 \mathrm{mM}$ dGTP, $50 \mu \mathrm{Ci}$ of $\alpha$ [32P] dCTP (BRIT, CCMB campus, Hyderabad) and 10 units of klenow fragments of DNA polymerase I. The reaction was incubated at room temperature for three hours.

\section{Southern Hybridization}

Southern hybridization was performed as described by Sambrook et al., (1989) with required modifications. Nylon filters carrying electrophoretically resolved DNA from banana tissue culture plant and infected were prehybridized in prehybridization solution (5X SSC, 5X Denhardt's solution, $1 \mathrm{mg} / \mathrm{ml}$ denatured salmon sperm DNA) at $62^{\circ} \mathrm{C}$ for 4 hours. The prehybridized filters were hybridized in hybridization solution (pre hybridization solution + radiolabelled probes at a concentration of $1 \mathrm{X} 106 \mathrm{cpm} / \mathrm{ml}$.) at $62^{\circ} \mathrm{C}$ for 18 hours. After hybridization, nylon filters were washed sequentially with $2 \mathrm{X}$ SSC $+0.1 \%$ SDS for 15 minutes at room temperature (twice), and $0.1 \mathrm{X}$ SSC $+0.1 \%$ SDS for 15 minutes at $62^{\circ} \mathrm{C}$. Then filters were dried at room temperature and exposed for autoradiography.

\section{Expression of recombinant coat protein gene in $E$. coli}

\section{Cloning in pET vector}

To express the coat protein gene in E. coli, the $\mathrm{CP}$ gene of BBTV was subcloned into expression vector pET28a (+) at EcoRI and HindIII site. The ligated product was transformed into competent $E$. coli strain BL21cells. The recombinant colonies were selected by colony PCR and restriction digestion analysis.

\section{Induction of coat protein gene in $E$. coli}

The E. coli strain, BL21 harbouring the plasmid pET 28a (+) CP was streaked separately on LB agar plate with appropriate antibiotics and incubated at $37^{\circ} \mathrm{C}$ for $12-16 \mathrm{~h}$ so as to get isolated individual colonies. Single colony was inoculated in LB broth containing appropriate antibiotics and grown on a rotary shaker $(200 \mathrm{rpm})$ at $37^{\circ} \mathrm{C}$ for $16 \mathrm{~h}$. Fifty $\mathrm{ml}$ of LB broth was inoculated with $1 \%$ of overnight grown culture and it was incubated at $37^{\circ} \mathrm{C}$ and $200 \mathrm{rpm}$ till the OD reaches $0.3-0.5$ at $595 \mathrm{~nm}$. One $\mathrm{ml}$ of the aliquot was taken in an eppendorf and centrifuged at 10,000 rpm for 5 min., and the pellet was dissolved in $50 \mu \mathrm{l}$ of the laemmli buffer $(0.06 \mathrm{M}$ Tris-HCl, $\mathrm{pH} 6.8, \quad 10 \%$ glycerol, 5\% $\beta$-Mercaptoethanol and 2\% SDS) and stored at $-20^{\circ} \mathrm{C}$ for later use as uninduced culture. The remaining culture was induced by the addition of IPTG (isopropyl$\beta$-D-thiogalactopyranoside), to a final concentration of $1 \mathrm{mM}$. The culture was allowed to grow at $37^{\circ} \mathrm{C}$ and the aliquot was collected at 3 and $6 \mathrm{~h}$., after incubation and the pellet was dissolved in Laemmli buffer (Laemmli, 1970) and stored at $-20^{\circ} \mathrm{C}$.

\section{SDS-PAGE analysis}

The glass plates were cleaned thoroughly with water followed by alcohol and placed in a casting unit. The separating gel mixture was poured in the glass plate assembly and overlaid with a film of isopropanol to avoid trapping of any air bubble and uniform gel surface. After polymerization, the alcohol layer was removed, rinsed with water and 
blotted with filter paper. The stacking gel mixture was then poured and the comb was placed on top of the sandwich. After polymerization, the comb was carefully removed and wells were rinsed with electrode buffer before loading the samples. The protein samples were mixed with $1 \times$ loading dye, boiled for $2 \mathrm{~min}$ and then loaded. Electrophoresis was carried in a $1 \times$ buffer (Tris 0.025M; Glycine $0.192 \mathrm{M}$ and SDS $0.1 \%$ ) at constant current of $15 \mathrm{~mA}$ till the dye front reached the separating gel. The current supply was then increased to a constant supply of $30 \mathrm{~mA}$ till the blue dye reaches the bottom. After the electrophoretic run, the gel unit was dismantled and gel was fixed using a fixative (Methanol; acetic acid; water, 4:1:5 ratio) and stained in a Coomassie Brilliant Blue solution for $12 \mathrm{hrs}$. The gel was destained until the background became colorless and the gel was documented using Alphaimager (AlphaInnotech, USA).

\section{Results and Discussion}

\section{Cloning and sequencing of the ' $\mathrm{CP}$ ' Gene of BBTV}

The 'CP' gene-specific primers of BBTV were designed using the conserved region in the ' $\mathrm{CP}$ ' gene. They are used for the complete amplification of the ' $\mathrm{CP}$ ' gene in the BBTV infected hill banana plants. The PCR products were resolved on $0.8 \%$ agarose gel and an expected size of $513 \mathrm{bp}$ was observed. The full length ' $\mathrm{CP}$ ' gene (513 bp) was then eluted from the $0.8 \%$ agarose gel and cloned into the T/A cloning vector, $\mathrm{pTZ} 57 \mathrm{R} / \mathrm{T}$ and named as pHBScp. The ligated product was then transformed into the E. coli strain (DH5 $\alpha$ ) and was selected on ampicillin containing medium. The recombinant colonies were identified by colony PCR using the same ' $\mathrm{CP}$ ' gene specific primer and one of positive clones was selected and further confirmed by releasing the cloned fragment using restriction enzymes, KpnI and HindIII. The selected three recombinant clones were sequenced (Fig. 3). Sequencing has resulted in a length of $513 \mathrm{bp}$ and the homology search of the sequence using NCBI blast (Altschul et al., 1997) showed similarity (99\%) to the reported ten ' $\mathrm{CP}$ ' gene sequences and are 98\% similar to four ' $\mathrm{CP}$ ' gene sequences. The identity search was made with BLASTX algorithm using the same nucleotide sequence.

\section{Southern hybridization analysis}

To confirm the virus infection and virus load at two different (juvenile stage and vegetative stage) stages, the five plant samples each from infected and healthy banana samples were subjected to southern blot hybridization and virus infection was confirmed using $\mathrm{CP}$ gene specific probe of BBTV. DNA of the banana samples both infected and healthy was restricted with restriction endonucleases, HindIII, the products were electrophoratically resolved, transferred to nylon membrane and hybridized against radiolabeled probes prepared using the BBTV $\mathrm{CP}$ gene. Hybridization of the blot with BBTV CP gene probe showed that no signal was observed in case of healthy plant control indicating free from BBTV infection, whereas the infected sample showed strong hybridization signal indicates the presence of BBTV (Fig. 4). Due to the presence of excessive phenolic compounds, they formed smeared lanes with faint bands.

\section{Expression of BBTV coat protein in $E$. coli}

The BBTV coat protein expressed (Fig. 5) in E. coli was subjected to SDS-PAGE analysis. The expression of BBTV coat protein was found in very low at 1-6 hour of incubation in IPTG induction and low level of expression was found at 7 and 8 hours of incubation in IPTG induction (Fig. 6). 
Figure.1 Dark green patches of BBTV infected leaf sheath

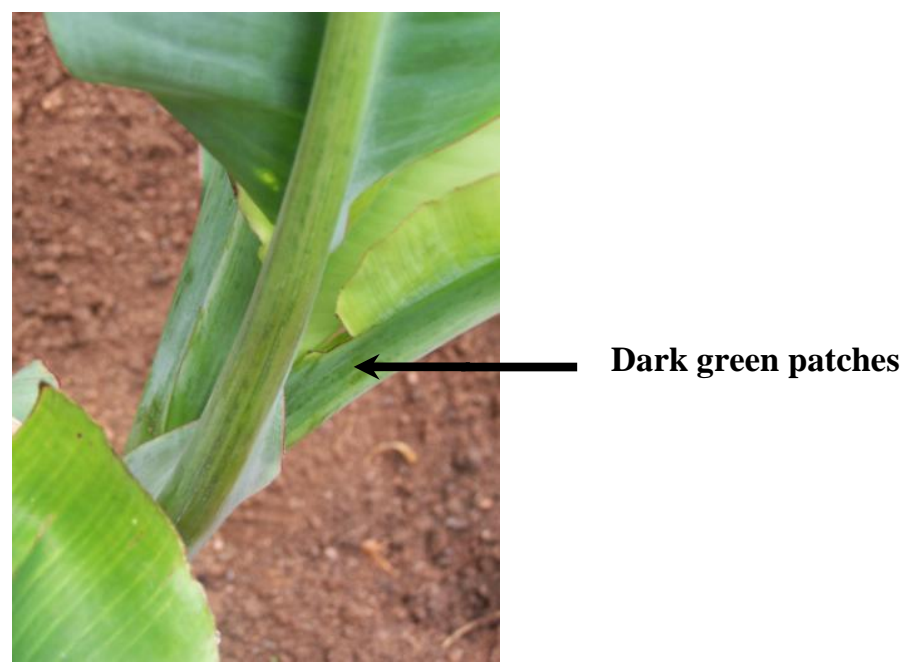

Figure.2 Field view of healthy and BBTV infected banana

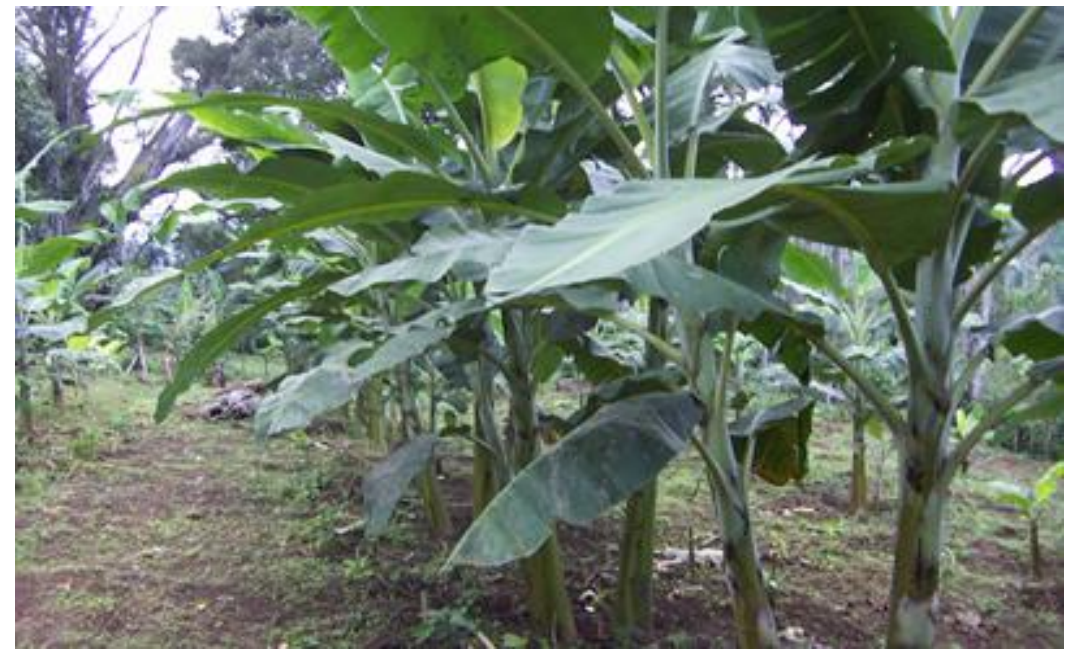

Figure.3 Confirmation of Recombinant clones by Colony PCR analysis, M- 100 bp ladder, 1- Coat protein $(C P)$ gene (513 bp), 2- Negative control (Tissue culture Plantain).

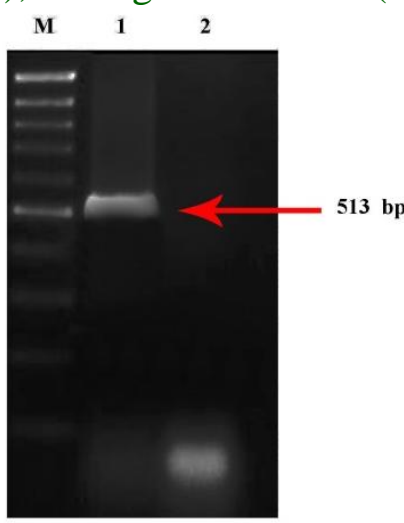


Figure.4 Southern blot analysis at Juvenile stage and Vegetative stage, PC - Positive control (Cloned Coat Protein Plasmid), NC - Negative control (Tissue culture Certified Plantain), IBBTV infected plantain and $\mathrm{H}$ - Healthy plantain

\section{Juvenile Stage \\ Vegetative Stage \\ PC NC I1 I2 I3 I4 I5 H1 H2 H3 H4 H5 \\ PC NC I1 I2 I3 I4 I5 H1 H2 H3 H4 H5}
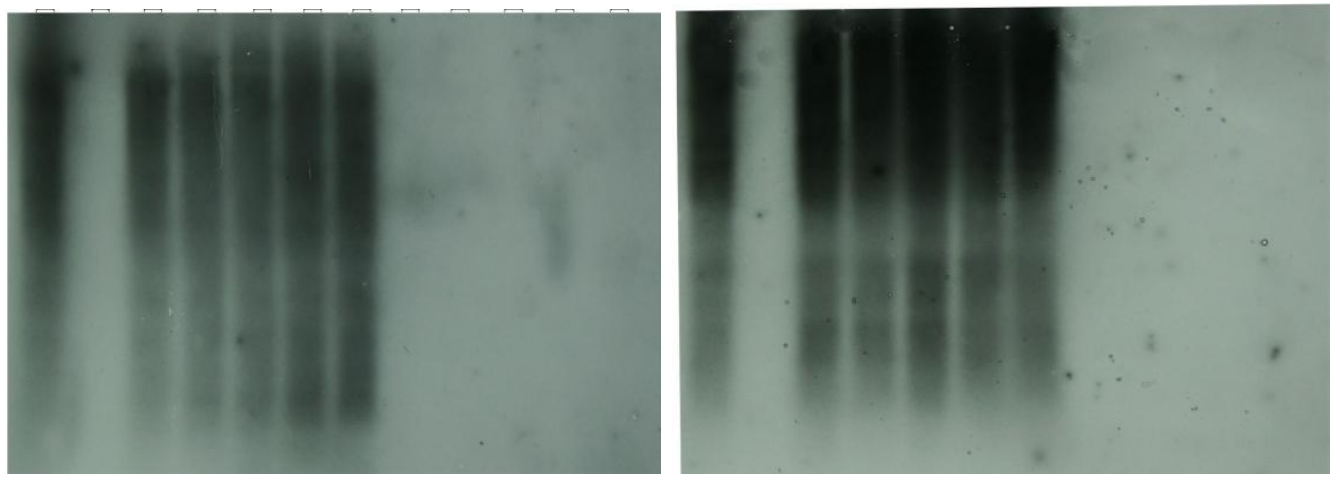

Figure.5 Cloning of pET $-28 \mathrm{a}(+)$ vector with $C P$ gene

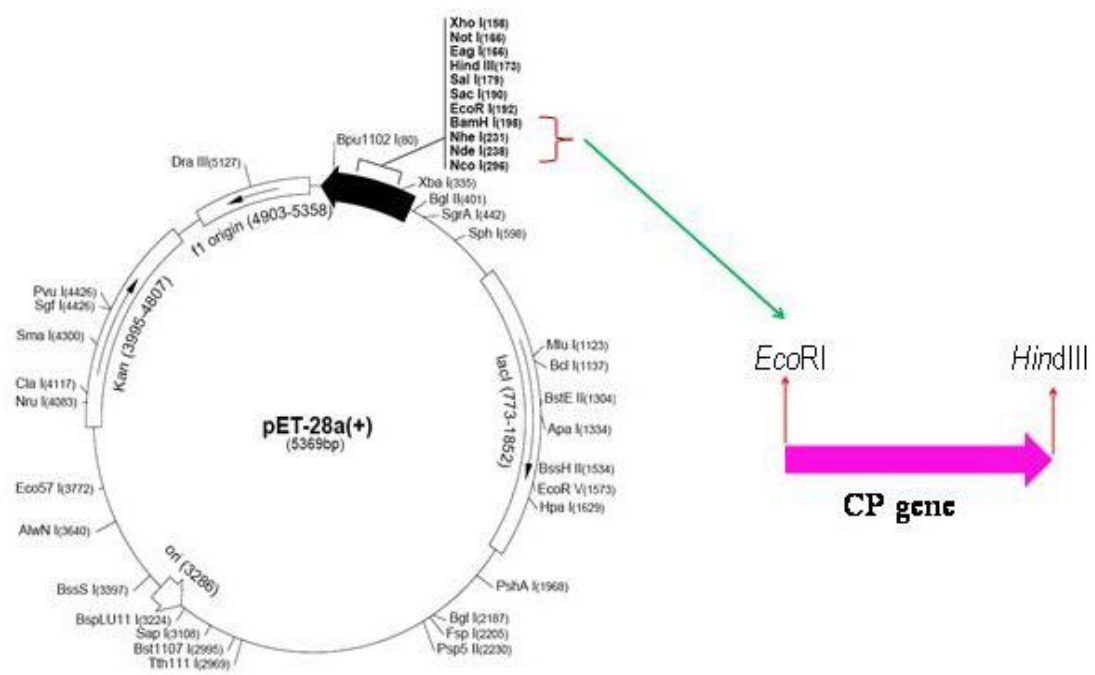

Figure.6 BBTV coat protein, M- Protein marker, C -pET 28a(+) vector (control), 3h, 6h - hours after IPTG induction

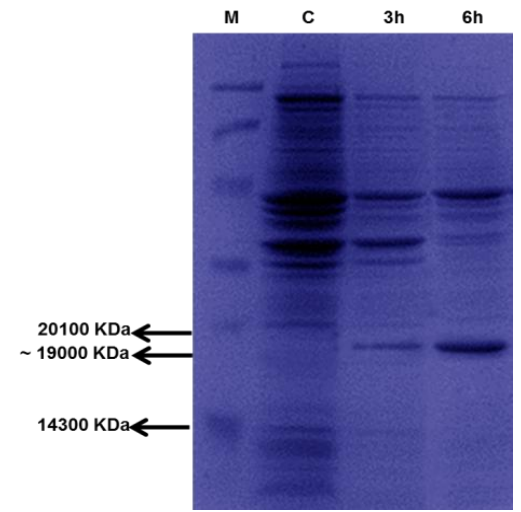


Table.1 Primer sequences for amplifying gene-specific sequences.

\begin{tabular}{|c|c|c|}
\hline \multicolumn{1}{|c|}{ Primer name } & \multicolumn{1}{|c|}{ Sequence } & Base pairs \\
\hline$C P$ gene forward primer & 5'-ATGGCTAGGTATCCGAAG-3' & 18 \\
\hline$C P$ gene reverse primer & 5'-TCAAACATGATATGTAATTC-3' & 20 \\
\hline
\end{tabular}

Banana is one of the most important fruit crop grown in most of the southern states of India. Several banana cultivars are under cultivation in India and hill banana is one of the unique cultivar grown in the lower Paliney hills in Tamil Nadu. Hill banana cultivation is seriously affected by the disease caused by BBTV. BBTV is transmitted in a persistent manner by the banana aphid Pentalonia nigronervosa and causes a yellows disease in bananas, it was classified as a 'possible member' of the luteovirus group (Matthews, 1981). Further evidence supporting this classification is the reported occurrence of dsRNA in BBTV infected plants but not in corresponding healthy plants (Dale et al., 1986). Selection of disease free planting material is one of the very important techniques in banana cultivation. Identification of BBTV infection in the planting material/suckers is very difficult as the symptom development is not visible at the early stage of infection. Several reports are available for the molecular detection of the plant virus in different crops using PCR and ELISA method. Immunological detection using technique such as ELISA is not effective as the virus is present in low tire in the banana plant. There is only one successful report of ELISA based detection of BBTV. Most of the recent literature showed that BBTV detection was effective using PCR method (Mansoor et al., 2005). PCR based detection technique, had the advantage of amplifying the target nucleic acid present even at very low level and it had become an attractive technique for the diagnosis of many plant viral diseases (Henson and French, 1993; Xie and Hu, 1994; Hafner et al., 1997a, Chandrasekar et al., 2011).
The CP coded by the DNA-3 component of the BBTV has been used for virus detection because of its important role in viral particles packing and disease establishment and has been consistently associated with BBTD in Asian countries group. An attempt was made to develop BBTV detection protocol utilizing the $\mathrm{CP}$ gene specific primers.

In order to, PCR amplification using CP specific primer gave amplicon of expected size (513 bp) with DNA isolated from infected hill banana plant. A common problem in the use of PCR for diagnostic purposes is, that it needs a good quality DNA. Plant species which contains high phenolic shows false-negatives i.e., even though the target viral DNA is present but still fail to amplify because of the quality of the DNA taken for PCR analysis. So the amplification of a PCR by using the internal control primer will possibly demonstrates the absence of PCR inhibitors in banana DNA samples and can provide some level of confidence on a diagnostic PCR reaction that is negative for the presence of BBTV. BBTV detection method using internal control primer and BBTV Rep gene primer was reported by Mansoor et al., (2005). Potential problems in PCR include false negatives due to reaction failure or false positives due to contamination (Chandrasekar et al., 2011). False negatives were often revealed in Southern blot technique.

Harding et al., (1991) used the Southern blot technique to detect the presence of BBTV in banana tissue and in aphids. In the present study, to confirm the presence of BBTV (DNA-3) CP gene, Southern hybridization 
analysis was performed. Southern hybridization analyses against the radiolabeled probes prepared from BBTV CP gene. The experiment performed with samples collected at two banana growth stages viz., juvenile and vegetative stage. From each stage five samples of infected and healthy samples were collected. The result indicates that all found in both stages. Normally banana plants has more mucilage and phenolic compound, in Biotic stress condition the phenolic, abscisic acid, ethylene, jasmonic acid, and salicylic acid levels are increased, here the BBTV plays major role of stress factor, where the phenolic levels are more elevated. Due to the presence of excessive phenolic compounds, they formed smeared lanes with faint bands. Infected plants had similar level of, hybridization signal in both stages, in the healthy plants no hybridization signal was seen. Harding et al., (1991) have showed the virus like particles are associated with banana bunchy top disease contains small singlestranded DNA. They have used southern blot method to analyze the expression of virus like particles with extracts from sucrose gradientpurified BBTV, healthy banana plant and partially purified BBTV. Their studies have also shown that the expression was seen only at the infected plants not in the healthy plants. Coat protein expressed in E. coli showed very low level of coat protein accumulation as revealed by SDS-PAGE analysis. The low level of coat protein accumulation may be due to the small size of the protein not being stably present in the E. coli cells. In contrast, Harding et al., (1991) and Wanitchakorn et al., (2000) used the SDS-PAGE they have got expression at a molecular weight of 20100KDa.

\section{Research involving human participants and/or animals}

It does not involving in the any Human participants and Animals. It is confirmation of banana bunchy top virus (BBTV) infection study. I confirm that all the research meets the ethical guidelines, including adherence to the legal requirements of the study country.

\section{Abbreviations \\ BBTV- Banana Bunchy Top Virus \\ $\mathrm{CP}$ - coat protein \\ PCR- Polymerase chain reaction}

\section{Acknowledgement}

I thank the Chairman of Department of Plant Biotechnology, Centre on Plant Molecular Biology and Biotechnology, Tamil Nadu Agricultural University, Coimbatore for providing all the facilities for molecular work, The Head, Horticultural Research Station, Thadiyankudisai, Tamil Nadu Agricultural University, Coimbatore for the field facility and the National Research Centre for Banana (NRCB) Trichirapalli, for providing the certified hill banana suckers free from BBTV infection planting material for field trial.

\section{References}

Altschul S.F, Madden T.L, Schaffer A.A, Zhang J., Zhang Z., Miller W, Lipman D.J., 1997. Gapped BLAST and PSTBLAST: a new generation of protein database search programs. Nucleic Acids Res 25: 3389-3402.

Amain I, Qazi J, Mansoor S, Llyas M, Briddon R.W., 2008. Molecular characterization of banana bunchy top virus (BBTV) from Pakistan. Virus genes 36:191-198.

Beetham P.R, Harding R.M, Dale J.L., 1999. Banana Bunchy top virus DNA-2 to 6 are monocistronic. Arch Virol 144: 89105

Burns T.M, Harding R.M, Dale J.L., 1994. Evidence that banana bunchy top virus 
has a multiple component genome. Arch Virol 137:371-380.

Burns T.M, Harding R.M, Dale J.L., 1995. The genome organization of banana bunchy top virus: analysis of six ssDNA components. J Gen Virol 76: 14711482.

Chandrasekar A, Kalaiponmani K, Elayabalan S, Kumar K.K, Angappan K, Balasubramanian P., 2011. Screening of banana bunchy top virus through multiplex PCR approach. Arch Phytopathol Plant Protect 19:19201925.

Dale J.L., 1987. Banana bunchy top: an economically important tropical plant virus disease. Adv Virus Res 33: 301 325

Dale J.L, Philllips D.A., Parry J.N., 1986. Double-stranded RNA in banana plants with bunchy top disease. J. Gen. Virol. 67:371-375

Edwardsand M.S, Gibbs R.A., 1994. Multiplex PCR: Advantages development and applications. PCR Methods Appl 3:65-75

Elnifro E.M, Ashshi A.M, Cooper R.J, Klapper P.E., 2000. Multiplex PCR: Optimization and Application in Diagnostic Virology. Clin Microbiol Rev 13:559-570.

Grieco F, Gallitelli D, 1999. Multiplex reverse transcriptase polymerase chain reaction applied to virus detection in globe artichoke. J Phytopathol 147:183185.

Hafner G.J, Harding R.M, Dale J.L., 1997a. A DNA primer associated with banana bunchy top virus. J Gen Virol 78:479486.

Hafner G.J, Stafford M.R, Wolter L.C, Harding R.M, Dale J.L., 1997b. Nicking and joining activity of banana bunchy top virus replication protein in vitro. $\mathbf{J}$ Gen Virol 78:1795-1799.
Harding R.M, Burns T.M, Dale J.L., 1991. Virus-like particles associated with banana bunchy top disease contain small single stranded DNA. J Gen Virol 72:225- 230 .

Henson J.M, French C.R., 1993. The polymerase chain reaction and plant disease diagnosis. Annu Rev Phytopathol 31:81-109.

Higgins D.G, Sharp P.M., 1988. CLUSTAL. A package for performing multiple sequence alignment on a microcomputer. Gene 73:237-244

Horser C.L, Karan M, Harding R.M, Dale J.L., 2001. Additional Rep-encoding DNAs associated with banana bunchy top virus. Arch Virol 146:71-86

John S.J, Briddon R.M, Mansoor S, Bedford I.D, Pinner S.M, Saunders K, Stanley J.Y, Zafar K.A, Malik P., 2001. Identification of DNA components required for induction of cotton leaf curl disease. Virol 285:234-243.

Karan M, Harding R.M, Dale J.L., 1994. Evidence for two groups of banana bunchy top virus isolates. J Gen Virol 75:3541-3546.

Karan M, Harding R.M, Dale J.L., 1997. Association of banana bunchy top virus DNA components 2 to 6 with bunchy top disease. Mol Plant Pathol online: 18

Katul L, Maiss E, Morozov S.Y, Vetten H.J., 1997. Analysis of six DNA components of the faba bean necrotic yellows virus genome and their structural affinity to related plant virus genomes. Virology 233:247-259.

Landgraf A, Reckmann B, Pingoud A., 1991. Direct analysis of polymerase chain reaction products using enzyme linked immunosorbent assay techniques. Annu Biochem 198:86-91

Laemmli, O. K., 1970. Cleavage of structural proteins during the assembly of the head 
of bacteriophage T4. Nature, 227: 680685.

Mansoor S, Qazi J, Amain I, Khatri I.A, Khan A.I, Raza S, Zafar Y, Briddon R.W., 2005. A PCR based method, with internal control, for the detection of BBTV in banana. Mol Biotechnol 30:167-169.

Matthews R.E.F., 1981. Classification and nomenclature of viruses. Intervirol 16:53-60

McManus P.S, Jones A.L., 1995. Detection of Erwinia amylovora by nested PCR and PCR-dot-blot and reverse blot hybridizations. Phytopathol 85:618-623

Menzela W, Jelkmann W, Maiss E., 2002. Detection of four apple viruses by multiplex RT-PCR assays with coamplification of plant mRNA as internal control. J Virol Methods 99:8192.

Meunier A, Schmit JF, Stas A, Kutluk N, Bragard C., 2003. Multiplex reverse transcription PCR for the simultaneous detection of Beet necrotic yellow vein virus, Beet soil borne virus, and Beet virus $\mathrm{Q}$ and their vector Polymyxa betae KESKIN on sugar beet. Appl Environ Microbiol 69:2356-2360.

Mullis KF, Faloona F, Scharf S, Saiki R, Horn G, Erlich H., 1986. Specific enzymatic amplification of DNA in vitro: the polymerase chain reaction. Cold Spring Harb Symp Quant Biol 51:263-273.

Nassuth A, Pollari E, Helmeczy K, Stewart S, Kofalvi S.A., 2000. Improved RNA extraction and one-tube RT-PCR assay for simultaneous detection of control plant RNA plus several viruses in plant extracts. J Virol Methods 90:37- 49.

Olmos A, Bertolini E, Cambra M., 2002. Simultaneous and cooperational amplification (Co-PCR): a new concept for detection of plant viruses. J Virol Methods 106:51-59.
Pearson W.R, Lipman D.J., 1988. Improved tools for biological sequence comparison. Proc Natl Acad Sci 85:2444-2448.

Sambrook J, Fritsch E.F, Maniatis T., 1989. A Laboratory Manual, 2nd edn. Cold Spring Harbor, NY: Cold Spring Harbor Laboratory Molecular Cloning

Singh R.P, Kurz J, Boiteau G., 1996. Detection of stylet-borne and circulative potato viruses in aphids by duplex reverse transcription polymerase chain reaction. J Virol Methods 59:189-196

Stellrecht K.A, Woron M, Mishrik N.G, Venezia R.A., 2004. Comparison of Multiplex PCR Assay with Culture for Detection of Genital Mycoplasmas. J Clin Microbiol 42 (4):1528-1533.

Su H.J, Tsao L.Y, Wu M.L, Hung T.H., 2000. Biological and molecular categorization of strains of BBTV. J Phytopathol 151:290-296.

Tettelin H, Radune D, Kasif S, Khouri H, Salzberg S.L., 1999. Optimized multiplex PCR: efficiently closing a whole genome shotgun sequencing project. Genomics 62:500-507.

Thomas J.E, Dietzgen R.G., 1991. Purification, characterization and serological detection of virus-like particles associated with banana bunchy top disease in Australia. J Gen Virol 72:217-224

Thompson J.D, Gibson T.J, Plewniak F, Jeanmougin F, Higgins D.G., 1997. The CLUSTALX windows interface: flexible strategies for multiple sequence alignment aided by quality analysis tools. Nucleic Acid Res 25:4876-4882

Tien J.E, Xin L.Z., 2005. Cloning and sequencing of DNA components of Banana bunchy top virus Hainan isolate. Chinese J Agri Biotechnol 2:91-97.

Tripathi L, Tripathi J.N, Tushemereirwe W.K., 2004. Strategies for resistance to bacterial wilt disease of bananas 
through genetic engineering. Afr J Biotechnol 3 (12):688-692

Valerie K, Thomas J.E, Sharman M, Mademba-Sy F., 2001. First record of banana bunchy top disease in New Caledonia. Australasian Plant Pathol 30:71

Vansluys M.A, Monteiro-Vitorello C.B, Camargo Menck L.E.A, Da Silva C.F.M, Ferro A.C.R, Oliveira J.A, Setubal M.C, Kitajima J.C., 2002. Comparative genomic analysis of plantassociated bacteria. Annu Rev Phytopathol 40:169-189.

Wanitchakorn R, Harding R.M, Dale J.L., 1997. Banana bunchy top virus DNA-3 encodes the viral coat protein. Arch Virol 142:1673-1680

Wanitchakorn R, Harding R.M, Dale J.L., 2000. Sequence variability in the coat protein of two groups of banana bunchy top isolates. Arch Virol 145:593-602

Wu R.Y, Su H.J., 1990. Purification and characterization of banana bunchy top virus. J Phytopathol 128:153-160.

Xie W.S, Hu J.S., 1994. Molecular cloning, sequence analysis and detection of banana bunchy top virus in Hawaii. Mol Plant Pathol 85:339-347.

\section{How to cite this article:}

Chandrasekar Arumugam, Kalaiponmani Kalaimughilan and Angappan Kathithachalam. 2017. Banana Bunchy Top Viral Coat Protein (CP) Gene Expression Studies at Molecular Level in Hill Banana cv. Sirumalai (AAB). Int.J.Curr.Microbiol.App.Sci. 6(6): 398-411. doi: https://doi.org/10.20546/ijcmas.2017.606.047 